Chapter Title: Christian Citizenship, Evangelical NGOs and the Ethics of Holistic Rehabilitation among Socially Marginalised Groups in Côte d'Ivoire Chapter Author(s): Boris Koenig

Book Title: Faith and Charity

Book Subtitle: Religion and Humanitarian Assistance in West Africa

Book Editor(s): Marie Nathalie LeBlanc, Louis Audet Gosselin

Published by: Pluto Press. (2016)

Stable URL: http://www.jstor.org/stable/j.ctt1gk0810.14

JSTOR is a not-for-profit service that helps scholars, researchers, and students discover, use, and build upon a wide range of content in a trusted digital archive. We use information technology and tools to increase productivity and facilitate new forms of scholarship. For more information about JSTOR, please contact support@jstor.org.

Your use of the JSTOR archive indicates your acceptance of the Terms \& Conditions of Use, available at http://about.jstor.org/terms

Pluto Press is collaborating with JSTOR to digitize, preserve and extend access to Faith and Charity 


\title{
9 \\ Christian Citizenship, Evangelical NGOs and the Ethics of Holistic Rehabilitation among Socially Marginalised Groups in Côte d'Ivoire
}

\author{
Boris Koenig
}

In recent years, numerous Ivorian Evangelical non-governmental organisations (NGOs) have engaged in activities that combine humanitarian aid with proselytisation. Indeed, for the leaders and members of these organisations, development cannot be reduced to material considerations; it also encompasses a spiritual dimension. This holistic approach to development is inextricably linked to 'lifestyle evangelism', which refers to living in the image of Christ while giving an example to non-believers, in the hope the latter will transform their own lives and embrace Christianity (Bornstein 2005: 50-51). However, while all Christians arguably share a desire to spread their religion, 'they certainly debate and disagree about approaches to spreading the gospel and proper conceptions of persuasion, proselytisation, evangelisation, proclamation and mission' (Bunge 2014: 209).

In light of these observations, this chapter analyses evangelisation strategies and the logic of lifestyle evangelism as they have been applied by Evangelical NGOs operating in Côte d'Ivoire. In particular, I focus on the holistic development of marginalised groups of adolescents and adults. The analysis itself focuses on the humanitarian aid and religious programming offered by Reformation, a transnational Evangelical organisation active in Côte d'Ivoire. Faith-based NGOs (fbNGO) like this one seek to improve the living conditions of drug addicts, vagrants, sex 
workers, (ex-)convicts, 'troubled adolescents', orphans and street children. Created in the 1980s, Reformation initially reached out to people with drug and alcohol addictions in Spain. Beginning in 1996, a group of European missionaries expanded the organisation's operations to Côte d'Ivoire and other West African countries. Today, Reformation pursues a wide range of activities in 70 different countries. Its efforts to provide humanitarian aid offer an interesting example of a holistic approach to development that addresses both the material and spiritual needs of beneficiaries, and in which religion concerns itself with all aspects of life' (Bornstein 2005: 49). Reformation's activities also provide an opportunity to reflect on the growing role of fbNGOs in the construction of alternative models of socioeconomic development, ethics and citizenship.

In the 1980s, Western countries imposed structural adjustment programmes on Côte d'Ivoire as well as many other African nations. These programmes greatly restricted the ability of governments to support vulnerable populations through social programmes. In Côte d'Ivoire, the situation was further exacerbated by the socio-political crisis of 2002-12. In the meantime, Catholic, Evangelical and Muslim religious institutions greatly expanded their traditional role in assisting vulnerable groups. In this context of neoliberalism, the last decade has been particularly important for the 'NGO-isation' of faith-based activities in postcolonial African societies (Hearn 2002). Similar to other fbNGOs operating in Africa and beyond (Beaumont and Cloke 2012; Freeman 2012a; Hefferan et al. 2009; Redfield and Bornstein 2011), Reformation's activities often replace services formerly provided by the state, especially in the fields of education, employment and addiction services, as well as the reintegration of convicts, vagrants and street children. Established in Côte d'Ivoire for more than two decades, and active in several other West African countries as well, the organisation has increased substantially its humanitarian aid programmes over the course of its history. Furthermore, as faith-based organisations like Reformation have become increasingly important socioeconomic actors over the course of the last two decades, they have received the support of the Ivorian government, which recognises and supports 'the special role of Non Governmental Organisations in the implementation of the national policy on educational, social, and economic development in Côte d'Ivoire' (Côte d'Ivoire 2008).

Working at the crossroads of local and transnational religious support networks, Reformation does not see itself as simply 'filling the gap' created by the state's waning commitment to implementing social 
programmes and developing social policy, or its compromised ability to ensure good governance (Ferguson, 2006a; Hefferan et al. 2009; Kasfir 1998). Rather, as Jean Comaroff has argued in the context of certain revitalised religious communities in South Africa, organisations like Reformation have devoted themselves to creating 'their own, relatively autonomous forms of sovereignty, their own regimes of order, power, enrichment' (Comaroff 2012: 53-54). In particular, this chapter discusses how Reformation has gained a large degree of autonomy in how it carries out its humanitarian and spiritual programming thanks to an agreement it signed with the government of Côte d'Ivoire. Furthermore, I examine how the organisation promotes a model of civic engagement and participation in the public sphere that is closer to a Christian understanding of citizenship than the modern notion of subject-citizen (Comaroff and Comaroff 1999; O’Neill 2009, 2010a). From this perspective, it is important not to reduce citizenship to a legal status, but to consider how different forms of religiosity and civic practices are part of a larger process of cultural production (O’Neill 2009, 2010a). Such an understanding is central to Reformation's transnational rehabilitation programmes, which focus on 'conduct of conduct' by introducing marginalised individuals to Christian self-forming activities that vary little from country to country. Building on other works that explore the notion of Christian citizenship (O’Neill 2009, 2010a), I suggest that the desire to shape the behaviour of marginalised groups, expressed through evangelisation strategies that are central to the organisation's rehabilitation programmes, constitutes a form of civic engagement. The capacity of rehabilitated participants to establish themselves as witnesses to the work of God is fundamental to this expression of Christian citizenship. In particular, participants must become capable of convincing other marginalised citizens to enrol in the programmes offered by Reformation.

In line with the principles of entrepreneurship and market-based development that are central to neoliberal ideology, Reformation also provides participants in its rehabilitation programmes with opportunities to learn a trade. The participants' newfound skills are then applied to income-generating activities that support the ongoing expansion of the organisation's rehabilitation programmes throughout Côte d'Ivoire. In this way, like numerous other African Pentecostal and charismatic Christian movements, it appears to have adopted both a neoliberal discourse and neoliberal economic development strategies (Comaroff 2012; Freeman 2012b; Maxwell 1998; van Dijk 2012). However, in contrast to many 
other churches and faith-based organisations that share its commitment to a market economy, Reformation's rehabilitation programmes are not based on prosperity theology (Freeman 2012b; Marshall 2009; Maxwell 1998; Meyer 2007; van Dijk 2012). Rather than a biblical interpretation that presents material prosperity as a sign of divine blessing (R. Marshall 2001, 2009; Meyer 2007), they tend to reflect an Evangelical doctrine rooted in an other-worldly perspective. Thus, Reformation's rehabilitation programmes feature an ascetic lifestyle, closed communities governed by strict rules, a focus on reflexive self-transformation and devotion to the salvation of vulnerable fellow citizens.

Reformation's faith-based approach to humanitarian aid can be explained in terms of the Christian notion of 'brotherly love' and the parable of the Good Samaritan, both of which constitute 'models for Christian giving in which all in need equally deserve care' (Redfield and Bornstein 2011: 6, 10). Granted, the Christian commitment to egalitarianism echoes the concerns of secular humanitarian organisations committed to 'saving' the lives of those who are 'most in need'. However, the humanitarian aid provided by Reformation differs in terms of how the notions of 'self' and 'care' are defined (Redfield and Bornstein 2011: 10-13). Thus, the work of organisations like Doctors Without Borders reflects a 'presentist' conception of life by seeking to alleviate ongoing physical and psychological suffering (2011: 10-11). By contrast, the work pursued by Reformation reflects a holistic conception of humanitarian aid, which is characterised by the promotion of an ideology based on the idea of a 'good Christian life'. This holistic approach encompasses and combines both the material and spiritual dimensions of life (Bornstein 2005; LeBlanc and Koenig 2014; Occhipinti 2009).

Based on ethnographic fieldwork conducted in the Ivorian metropolis of Abidjan and surrounding areas in 2012, this chapter explores the processes through which participants in Reformation's rehabilitation programmes cultivate their relationship with themselves and with God, with the aim of changing their lifestyles and those of their fellow citizens. My analysis draws attention to the ethics of these rehabilitation programmes, which oscillate between faithful self-examination and the practice of active Christian citizenship. My findings are based on participant observation in three of Reformation's Christian rehabilitation centres, as well as in a public jail. Over a period of four months, I followed residents as they completed their daily activities. I also conducted interviews, both with 
Reformation members and with some of the first Evangelical missionaries to work in West Africa.

The chapter begins by briefly discussing how the activities of Evangelical NGOs in Côte d'Ivoire have focused on the holistic rehabilitation of marginalised individuals. This highlights how Reformation's activities are unique in terms of both their national and international scope, despite offering forms of humanitarian aid that are similar to the charitable activities widely pursued by other NGOs. The opening section also underscores how Reformation stands out in relation to other local Evangelical NGOs active in the humanitarian sector, because of the complexity of its transnational organisational structure and its unique relationship with the government in Côte d'Ivoire. Second, I describe the process of rehabilitation and the logic of Christian pastoral discipline, with its reliance on self-governance and self-transformation activities (Laidlaw 2014; Marshall 2009; O’Neill 2010a; Sharp 2009). Examples of the latter include daily prayers, in-depth Bible study, the sharing of testimonials, and discussions of biblical themes. This section focuses on the relationship between moral codes and the reflexive self-forming activities through which residents break with their past experiences and cultivate their virtue. I show how these Christian self-forming activities follow an 'ethics of quarantine', ${ }^{1}$ insofar as they take place in closed centres where residents are geographically and socially isolated from familiar social contexts. Furthermore, this ethics of quarantine is also reflected in the decision made by many residents to live at a centre permanently, in contrast to other Christian addiction treatment programmes that have a defined length. These permanent residents remain available to pursue the ongoing expansion of the organisation's activities throughout the country. Finally, I show how full participation in Reformation's humanitarian and proselytisation campaigns provides residents with the means to govern their conduct as witnesses to Jesus Christ and to actively live as 'good' Christian citizens dedicated to the care and salvation of other marginalised men and women. I suggest that rehabilitated residents chiefly display their Christian citizenship by encouraging their fellow marginalised citizens to participate in the organisation's programmes, as well as by soliciting potential donors to help maintain and expand the NGO's activities. This form of lifestyle evangelism and its associated evangelisation strategies fundamentally depend on a constant supply and the continuous repetition to the largest possible audience of stories about the 'miraculous' influence of God and Reformation in the lives of residents. 
Given the sexual segregation that prevails in Reformation's programmes, my observations mainly apply to (young) men, a category of individuals who account for the majority of residents at the organisation's centres in Côte d'Ivoire. Granted, an analysis of the role of women, their spatial segregation from men, and gender dynamics at Reformation would be both welcome and relevant. However, it is beyond the scope of this study. Nor does this chapter thoroughly address the role and place of children in Reformation's rehabilitation programmes. However, age dynamics have been addressed at more length in other studies that explore the activities of faith-based Ivorian NGOs dedicated to the evangelisation of children (LeBlanc and Koenig 2014).

\section{Social Marginalisation and Christian NGOs in Côte d'Ivoire}

Prior to undertaking an in-depth case study of Reformation, I had identified 14 local Christian Evangelical NGOs that focus their humanitarian and spiritual activities on vulnerable groups. Examples of the latter include convicts, sex workers, street children, drug addicts and the homeless. ${ }^{2}$ I conducted interviews with officials from these NGOs, discussing organisational history and structure, past and current activities, support networks, as well as relationships with the government of Côte d'Ivoire ${ }^{3}$ and various other associations and faith-based organisations. These preliminary discussions uncovered several points that are key to understanding the work that these Christian NGOs do with vulnerable groups in Côte d'Ivoire.

The majority of the 14 Evangelical NGOs had been created during the previous decade, in the hope that formal organisational structures would help provide them with the credibility necessary to attract donations from national and international development agencies. Their creation was also motivated by a desire to introduce new organisational and operational models, different from those of Catholic and Evangelical hierarchies, that could support new forms of evangelisation. During my fieldwork in Abidjan, all ${ }_{14}$ Evangelical NGOs appeared to operate without any financial or technical support from national or international agencies. Rather, they were supported through the modest contributions of their founders and members. The organisations' activities were limited to carrying out various ad hoc and small-scale evangelisation campaigns, prayer gatherings and drives to distribute assistance such as school supplies, clothes, medicine and food. The beneficiaries were street children, prisoners, orphans, sex 
workers and drug addicts. A large number of local Evangelical NGOs expressed a desire to establish Christian rehabilitation centres with vocational training and social reintegration programmes. However, in the absence of a significant local or transnational support network, none were able to realise such projects.

Among all of the Catholic, Evangelical and Muslim NGOs I have encountered in Côte d'Ivoire, Reformation is the only one that has successfully initiated such a programme in the last couple of decades. In the 1990s, the transnational NGO Reformation International, which is headquartered in Spain, sought to establish a network of local NGOs for the rehabilitation of marginalised individuals in West Africa. Thus, the first centres in Côte d'Ivoire - as well as in other nearby countries including Ghana, Burkina Faso, Mali, Togo and Benin - were set up by a team of Spanish and Portuguese missionaries who had previously completed the organisation's holistic rehabilitation programme at Reformation centres in Europe. Since that time, the national NGOs established in West Africa have received supplies and funding from Reformation International, along with technical assistance in establishing new rehabilitation programmes that have remained relatively standard from one country to the next. Furthermore, the creation of the transnational NGO in Spain was accompanied by the founding of a new Evangelical Church to 'support and accomplish the work of evangelisation'. Thus, the leadership provided to national NGOs in West Africa also has a spiritual dimension. Indeed, the Church hierarchy is closely linked to that of the NGO. The founder and main leader of Reformation International is also the Church's main pastor. He is responsible for nominating and consecrating the leaders of the national NGOs, who serve as 'co-pastors' of the international Church and main pastors of their own territories. Within each country, a similar process is followed for the nomination and consecration of 'deacons' responsible for managing local rehabilitation centres established in various communities.

Members undergoing rehabilitation, also called 'Reformation workers', are at the bottom of the NGO's hierarchy. However, as discussed below, they can progressively rise within the organisation's hierarchy over the course of their rehabilitation. In Côte d'Ivoire, a wide range of individuals of every age, gender and faith enrol in Reformation's socio-spiritual rehabilitation programmes. At the time of my fieldwork in 2012, there were more than 600 residents in 12 centres located throughout the country. More than a hundred adult males had been at a centre for over five years 
dealing with problems tied to drugs and alcohol abuse, drug trafficking and other crime, or homelessness. Several of them had served prison sentences. There were 160 boys under the age of 12 , most of whom were orphans or street children. They attended a boarding school, which was completed in 2012. The NGO also served several dozen women of various ages who were former sex workers or drug addicts, as well as some 200 adolescent boys deemed troubled by their families, who placed them in a centre. Furthermore, the centres were home to an assortment of ex-convicts, vagrants, alcoholics and drug addicts. Finally, the Ivorian branch of Reformation hosted several dozen Spanish and Portuguese missionaries - men who had been rehabilitated at Reformation centres in Europe - as well as the Spanish pastor who leads the NGO in Côte d'Ivoire. The leader had himself been rehabilitated by Reformation and was a member of the first group of missionaries to arrive in West Africa.

In Côte d'Ivoire, Reformation accepts donations of supplies and money from individuals, businesses and various Evangelical groups. However, the organisation does not collaborate on projects with other Churches or fbNGOs. Rather, it seeks to develop its own activities and its own infrastructure. In 2008, Reformation expanded its socioeconomic and religious role in the public sphere by signing an agreement with the government to 'harmonise their activities and ensure complementarity', as well as to 'settle [...] questions related to the establishment and operation of the [NGO's] headquarters' (Côte d'Ivoire 20o8). Under this agreement, Reformation Côte d'Ivoire has 'the right to enact within its centres regulations for establishing therein the conditions necessary for their operation'. This agreement also provided for simplified immigration and emigration procedures for the NGO's foreign missionaries, as well as special tax and customs arrangements. The latter exempt Reformation from customs duties, as well as import and consumption taxes on goods associated with its activities. The Ivorian government nevertheless reserves the right to cancel the agreement if the NGO's activities run counter to its mission statement, which reads: 'Develop and assist the most vulnerable groups in society: the marginalised, the addicted, street children, and more generally all social cases requiring humanitarian assistance.' The remainder of this chapter provides an in-depth case study of the programmes developed by Reformation to address the material and spiritual needs of these groups. 


\section{The Ethics of Quarantine, Christian Pastoral Discipline and Reflexive Self-Transformation}

\section{The First Steps towards Holistic Rehabilitation}

During one of my first visits to a Reformation rehabilitation centre located in Abidjan, I shadowed Osmane as he went about his daily activities at the reception desk. A former alcoholic and drug addict, this 36-year-old former Muslim had been a resident for seven years. He converted to Evangelical Christianity during his residency, having spent much of his 2os experimenting with 'libertinism, a life of chaos'. Like the centre's other key personnel, Osmane is a rehabilitated member of Reformation who has been able to rise rapidly within the organisation's hierarchy. This reflects a very common practice in drug treatment communities all over the world (Hyde 2011). Shortly after Osmane and I began talking, a very weak-looking young man entered and immediately asked to join the centre. Osmane firmly responded:

The rule here is that once you join, you never leave. You will not be allowed to use drugs, smoke cigarettes, drink alcohol, carry cash, listen to secular music, or read non-Christian texts. You will engage in activities at the specified time. You will be able to call your parents after three months. After six months, you can arrange for someone to visit. Here, we do not fight, we do not steal. So tell me: Do you want to change? Do you really want to change?

The young man had begun coughing and Osmane told him he would have to get another pneumonia screening before he could move into the centre. When the prospective member objected, Osmane replied: 'If you cannot accept this condition, you will not be able to accept the rule' (Abidjan, August 2012).

This incident provides a good illustration of the moral codes, asceticism and disciplined community life that underpin Reformation's rehabilitation programmes. In contrast to Christian rehabilitation centres where residents are charged a fee (Hyde 2011; Sharp 2009; Zigon 2011), there is normally no charge for joining Reformation. However, residents are expected to remain at the centres over the long term and dedicate their lives to the organisation. ${ }^{4}$ As Osmane explained to the visitor, internal regulations prohibit stealing and physical or verbal violence, as well as the 
possession of money, cellular phones and non-Christian literature. The collective sharing of property is strongly encouraged. Normally, residents cannot leave the centre, although they can request permission once a year to visit their loved ones for a week. According to one supervisor, some members have run away multiple times. Some returned to the centre and decided to continue participating in the programme, while others did not.

All residents are required to follow not only a centre's rules, but also a strict and standardised three-step rehabilitation programme. For ex-prisoners, addicts, 'troubled adolescents' and alcoholics, the first step is a rest phase that includes cessation when relevant. Next, participants are taught to read and write (if necessary), given the opportunity to learn and practise a trade, and immersed in socio-cultural or Christian self-forming activities. The final step involves activities that take place outside the centre, including proselytisation and the solicitation of potential donors. Overall, the programme operates according to what can be called an 'ethics of quarantine'. New residents - be they street children, troubled adolescents, drug addicts or alcoholics - are systematically removed from social networks that might encourage them to leave the centre. Indeed, they are often transferred to centres located in another part of the country or even in a different West African country.

Life in one of Reformation's programmes begins with a three-month stay at one of the organisation's farms. Every day, all residents are expected to spend a few hours in activities such as livestock farming, general agriculture, maintenance, upkeep and prayers, with plenty of time also set aside for rest. Most of these farms are secured by walls that stand at least three metres tall and entrance doors that remain closed at all times. At the end of the three months, residents move to centres located in urban areas, where discipline and security are just as rigorous, and where spiritual activities take centre stage. Residents also acquire professional skills and are given the opportunity to engage in sports, theatre, reading and other socio-cultural activities. Vocational training in sewing, carpentry, construction and mechanical repair develops skills that can be used to clothe residents, build new centres and maintain equipment. ${ }^{5}$ Furthermore, Reformation follows the example of many Pentecostal congregations by partially financing its operations through profit-generating activities advertised on the exterior of church buildings (Comaroff 2012: 55). Reformation sells automotive and furniture repair services, cleaning services, as well as Christian books and other retail items. The organisation's theatre and musical groups can be hired to perform at private events, 
while some of its facilities are rented out as banquet halls for weddings and other events.

The centres have found that a reduction in food rations is the most effective punishment for residents who break the rules. ${ }^{6}$ Unruly residents are sometimes also transferred to a farm for a few weeks or to a centre in a different West African country for a few months. However, such forms of discipline are not considered the cornerstone of the rehabilitation process. Rather, 'it is Jesus who ultimately transforms [the person], not the discipline'. This is how the director of Reformation Côte d'Ivoire, a former drug addict and convict who was rehabilitated at a Reformation centre in Portugal, explained the logic behind the organisation's approach:

These rules were put in place because we are rebels, dirty. The principle behind rehabilitation is taking care of yourself, being responsible for yourself, your own room, your own clothes, before taking care of your neighbour. With the exception of toothbrushes and towels, all personal possessions are shared as part of communal life, to forge a sense of community. The freedom of the streets [is replaced by] a 5:30 wake-up call and a strict schedule that accounts for every hour of the day. To help your brother improve, a certain type of discipline in life is necessary. Members may fall again [relapse]; thus Jesus Christ and community life must be accepted as necessary to keep the light shining in their lives. (Abidjan, September 2012)

In the same vein, Osmane explained to me how Reformation's emphasis on spirituality is what sets its rehabilitation programmes apart from those run by secular humanitarian organisations:

We are a family, an Evangelical Christian centre. We are trying to erase a history of religious, ethnic and political conflict. Many have had experience with the Blue Cross, the Red Cross. But the treatments provided by these organisations do not free [participants] from alcohol and drugs. It is the Word of the Lord that restores, rehabilitates. (Abidjan, August 2012)

Reformation's rehabilitation programmes allow residents to break away from their social networks and destructive habits. The organisation's emphasis on making 'a complete break with the past' echoes the discourses of other Christian groups in Africa (Meyer 1998; Robbins 
2007). But contrary to how scholars normally describe the experiences of Evangelical or Pentecostal church members, this break with the past is not something that Reformation residents achieve during or following their participation in worship or deliverance services (for example, see LeBlanc 2003; Marshall 2009; Maxwell 1998; van Dijk 1997). Rather, it occurs as a result of their everyday activities in closed rehabilitation centres that are often even geographically removed from familiar social settings. It is also significant that Reformation's call for its members to break with the past does not include breaking with the 'spirit of poverty' or an embrace of the prosperity gospel (Freeman 2012b; Gifford 2007; R. Marshall 2001, 2009; Maxwell 1998; O’Neill 2010a). Rather, the organisation's interpretation of the Gospel produces rehabilitation programmes that reflect an ethics of asceticism. Thus residents and those who minister to them are required to abandon both their material possessions and their social lives in order to fully commit to a life of service and compassion towards their fellow marginalised citizens.

Looking at how daily self-forming activities cultivate residents' relationships with themselves is one way of better understanding the significance of this rift in residents' lives (Robbins, 2007). Here, I draw on Michel Foucault's analytic distinction between moral codes (the rules and regulations enforced by institutions, which individuals may obey and resist in different ways) and ethics (the ways in which individuals 'might take themselves as the object of reflexive action, adopting voluntary practices to shape and transform themselves in various ways') (Laidlaw 2014: 111). Clearly, Reformation's programmes reflect the legacy of a pastoral Christian ministry in which the figure of the shepherd carries the weight of his flock's conduct and takes responsibility for the souls of his followers (Foucault 2004). There is also no doubt that Reformation structures its residents' lives in such a way as to make certain choices more feasible. This does not, however, negate the importance of self-formation techniques that:

permit individuals to effect, by their own means, a certain number of operations on - their own bodies, their own souls, their own thoughts, their own conduct - and this in a manner so as to - transform themselves, modify themselves, and to attain a certain state - of perfection, happiness, purity, supernatural power. (Foucault as cited in Laidlaw 2014: 101; see also Foucault 1984) 
In the communal atmosphere of Reformation's Evangelical rehabilitation centres, residents work to achieve self-discipline, adjusting their minds with spiritual exercises that are meant, in the words of one resident, to give the 'Holy Spirit room to reside in them'. These 'technologies of the self' are in line with the 'monitoring and mapping of virtue, [which] have been Christian technologies of selfhood for centuries' (O'Neill 2010a: 61). Indeed, the importance placed on residents' relationships with themselves is reflected in the Christian therapies Reformation prescribes 'in quarantine'. The central components of the organisation's rehabilitation programmes are prayer (conversation with God), Bible study (during which residents evaluate their own conduct), sharing testimonies and life stories, and having residents give presentations on various biblical themes to their 'brothers and sisters in Christ'. These are all technologies of the self that also figure prominently in other rehabilitation programmes and in the Christian tradition more generally (Marshall 2009: 150-54; O'Neill 2010a; Sharp 2009: 39). Over a period of time, which may last several years, these self-forming activities give residents the ability to engage in an ongoing, reflexive process of self-transformation that produces a rift with their former lives. For example, Kouakou - a former drug addict who had been a member of Reformation for nine years - gave a presentation on 'spiritual gifts' during a festive fundraising event. His audience was composed of fellow residents from across southern Côte d'Ivoire, Reformation members from other West African countries, and guests from various Ivorian Evangelical Churches. Kouakou's speech is also similar in form to the ones that all residents practise every night for two hours. He began by asking,

A miracle at Reformation? Routine? We coughed up blood, still shackled to drugs. But Jesus came and set us free. I am a survivor, miraculously cured.... We are here at Reformation to fix ourselves, and we have a responsibility to ourselves, with the Word of God. Will we remain in sin so that grace abounds? Far from it! We who have died in sin, how can we keep living in sin? We will remain in chaos, and the Holy Spirit will come reside in us? No, he lives in men who constantly fight against evil with a spirit of labour, praise.... To each is given the gift of service, to be useful to society. We all have a gift before and we can share our spiritual gifts, but it's faith that is at the heart of spiritual gifts.... Me, I am among you, and I'm serving you. May he who would be great wash the feet, head of his neighbour. May he be a servant. We will all be recognised 
as great in the Kingdom of God because we have developed the gift of service. (Abidjan, September 2012)

By practising, giving and listening to this type of speech on a daily basis, residents are called to examine their individual and collective consciences. This constitutes one of the key self-forming activities during which residents 'cultivate themselves as ethical subjects' through their relationships with their peers (Laidlaw 2014: 83). It is through these testimonies about miracles that Jesus has worked in the lives of residents that a sense of belonging is created at Reformation. These self-forming activities also help residents to recognise the growing rift between their previous 'li[ves] of chaos' and the more virtuous ones that they lead at Reformation, so that 'the signs of change may be read, evaluated, and developed in an ongoing way' (Marshall 2009: 153). But as Kouakou essentially explained, the organisation's ability to 'save lost and vulnerable bodies and souls' depends largely on residents' enthusiasm for learning to be helpful and useful. They need to be willing to put effort and energy into serving and showing compassion to their fellow residents, as well as their 'neighbours' living outside the centres. As stated earlier in the chapter, this idea is tied to the notion of 'brotherly love' and the parable of the Good Samaritan. Thus, in the context of Reformation's rehabilitation process, the need for residents to be 'useful to society' and develop a sense of Christian citizenship is just as strong as the need for them to re-evaluate their own lives and rebuild their self-esteem.

\section{Compassionate Care, Witnessing, and Evangelism Among Vulnerable Peers}

The Performance of Christian Citizenship as the Last Step of the

\section{Rehabilitation Process}

Those residents who have been with Reformation the longest evaluate the rehabilitation of newer residents based on the latter's capacity to be 'witnesses to the work of Christ'. The leadership of the NGO and its various centres is structured according to the principle of who is 'the most faithful, who serves and truly considers their neighbour. ${ }^{8}$ While the pastor of Reformation International nominates and consecrates the directors of national NGOs, the latter choose the directors of local centres, who in turn appoint residents to positions of responsibility. At the beginning of 
the rehabilitation process, these responsibilities can include overseeing a dormitory, a kitchen, a workshop or a store. From there, residents can advance within the organisation's hierarchy, with some even taking responsibility for a local centre or a national rehabilitation programme. As the director of Reformation Côte d'Ivoire was quoted as saying in the previous section, promotions depend on the ability of residents to take responsibility for themselves, so they can ultimately provide assistance to marginalised individuals outside the walls of a centre. This section will focus on the final step in the rehabilitation process, during which residents play the role of 'witnesses to the work of Christ' through their social interactions with vulnerable groups that the organisation seeks to assist, as well as with various individuals and organisations solicited for material and financial support.

The ability of Reformation Côte d'Ivoire to continually expand its programmes and integrate a growing number of new members depends on residents' daily acts of compassion towards some of the most vulnerable individuals in society. As illustrated in Kouakou's speech, the process of ethical self-transformation that residents follow to become 'good Christian citizens' is based on the biblical imperative for persons of faith to put the needs of others above their own: 'Do nothing out of selfish ambition or vain conceit. Rather, in humility value others above yourselves, not looking to your own interests but each of you to the interests of the others' (Philippians 2: 3-4). In order to better understand how residents internalise this biblical injunction, this section focuses on the description and analysis of daily activities, while highlighting the importance of a particular form of evangelism that involves 'seek[ing] to live as witnesses to Jesus Christ' (Oxbrow 2014: 55-56; see also Bornstein, 2005; Marshall 2009; Sharp 2009).

For members of Reformation, the exercise of Christian citizenship is inseparable from the ability to become witnesses to Christ. However, it is important not to take an overly narrow perspective on civic engagement that reduces the idea of citizenship to the modern notion of subjectcitizen (Comaroff and Comaroff 1999). The latter refers to the legal status of an individual member of a nation-state, as well as the rights associated with that membership. Yet a number of observers have underscored how, in a context of globalisation and neoliberal politics, a form of 'disjunctive citizenship' has emerged. Thus, in a context of growing inequality and increasing poverty, the rhetoric of modern citizenship does not match the 
experience of modern citizens (see Comaroff and Comaroff 1999; O’Neill 2010a: 20).

In order to address this problem, some scholars have suggested turning to the concept of cultural citizenship, popularised by Miller (1998). When applied to the internal dynamics of religious communities and groups, cultural citizenship has been used to refer to 'spaces and actions that encourage public debate, promote the exchange of ideas and allow groups of individuals who are often marginalised, if not excluded, to express their identities and claim their own moral projects' (Gomez-Perez and LeBlanc 2007: 44). Likewise, O’Neill has proposed a way of conceptualising Christian citizenship that analyses how forms of religiosity and civic practices cease being distinct practices by contributing to a single process of cultural production (O’Neill 2009, 2010a). While adopting a similar approach to research on cultural citizenship, I also draw on studies inspired by the work of Michel Foucault in order to explore ways in which members of Reformation construct and perform their citizenship on the basis of Christian practices supported by the organisation's 'transnational apparatus of governmentality' (Ferguson 2006a; Ferguson and Gupta 2002; O’Neill 2009, 2010a).

While pursuing this approach, it is important to avoid focusing too tightly on what individuals active in a religious milieu learn about citizenship and participation in the public sphere (O’Neill 2009, 2010a). Granted, such a perspective can provide a deeper understanding of the forms of apprenticeship that members of Reformation engage in over the course of their rehabilitation. However, this didactic relationship is not the only one that shapes how residents construct themselves as citizens and perform Christian citizenship. Keeping in mind the spirit of the self-forming activities through which residents cultivate a virtuous subjectivity, O’Neill's observations on citizenship are especially relevant:

Christian rationality makes sense as a mode of citizenship when one takes seriously Foucault's notion that understanding governmentality means understanding the moral registers that prompt citizens to govern their conduct and the conduct of others and that these efforts at governing conduct constitute citizenship participation. (O'Neill 2009: 342)

Understood as a form of political rationality - and not merely as a cultural identity or a political status - citizenship rests on the question: 'What 
should the good citizen do?' (O'Neill 2010a: 14). For the rehabilitated members of Reformation, citizenship participation involves first relying on specific self-forming techniques to learn to govern themselves, and then becoming capable of helping other marginalised individuals to break away from a 'life of chaos'. From this perspective, it becomes clear that Reformation's model for social change involves oscillating between faithful self-examination and the practice of active Christian citizenship. As mentioned above, the ideology of the 'good Christian citizen' centres on biblical prescriptions requiring individuals to show compassion and serve their fellow citizens. Because of their experience as drug addicts, alcoholics, street children, troubled adolescents, sex workers and convicts - and their subsequent rehabilitation with the help of Reformation's Christian therapies - residents are able to act as 'witnesses to the work of Christ' before their fellow marginalised citizens. For what Osmane describes as a 'life of chaos' is exactly what rehabilitated residents experienced before joining Reformation. ${ }^{9}$ Thus, they are 'Motivated by the love of one's neighbour ... [to] bring assistance like angels sent by God to marginalised people living in the most disgusting environments'. ${ }^{10}$ Every day and every night, they scour the country's prisons, ghettos, drug houses, brothels, and places where the homeless and street children assemble. And whenever residents embark on these missions, they always do so in pairs to reduce the risk of one of them 'backsliding' and not returning to the rehabilitation centre.

For example, Isaac is a member of Reformation who cited 'testifying to the blessing of God in their lives', and displaying compassion in order to 'bring the maximum number of people to Jesus Christ' as the primary motivations behind his visits to Abidjan's public prison. Isaac explained that he had struggled with 'drugs, organised crime, crimes, and theft', been rejected by his family, and been incarcerated eight times before meeting a Reformation resident in 2003. This led him to 'make the decision to choose Jesus', and he now leads activities three times a week at the prison. I spent five days with Isaac and a few dozen prisoners who planned to rehabilitate themselves at a Reformation centre upon their release. He used donations of food and clothing to show compassion to the inmates, many of whom were deprived of any support other than their daily ration of 'penal rice'. Priority was given to those who attended Isaac's activities and to other incarcerated Christians. These offerings of what he called 'physical as well as spiritual food', a particularly evocative description of this distinctive form of faith-based humanitarian aid, afforded Isaac an opportunity to call 
on the prisoners to convert. One of the sermons he delivered in prison also addressed the logic behind Reformation's approach to social change:

Tell the person next to you that God does nothing by chance. If God has allowed you to be put in prison, it's to talk to you about many things. May God use you like an instrument. You will get out, you will return to your family, and you will be a useful instrument because you are not just anyone. That is why you are a precious being in the eyes of God. Your whole existence is useful. God chose you so that through you a whole nation may convert. Because through your testimony, many souls will be won for the Lord. Let us accept the Lord, walk with the Lord, live with the Lord.... Christ, he has a flaw. I tell you Christ has a flaw... Despite what you do, despite all that is negative, he supports you. Christ's flaw, do you know what it is? He loves us as we are. May the name of the eternal God be blessed, and may God use us as his children.

The emphasis on rehabilitating vulnerable individuals and improving their self-esteem as a form of Christian-inspired therapy echoes the results of recent research on prison chaplains and members of the Mara Salvatrucha gang in Guatemala (O’Neill 2010b). In the Central American context, Christian support groups provide incarcerated gang members with testimonies and books on morality to equip them with the tools necessary to control their inner world, regain their self-esteem and recognise moments when they feel the divine presence of the Lord. Likewise, there is a strong emphasis on self-esteem in the self-forming activities that Reformation members engage in, as well as in what they say to individuals they encounter outside of the centres. The process begins by highlighting an individual's opportunity to be useful to society if they choose to break with their lifestyle and join Jesus. The desired outcome is for these new converts to commit themselves to being witnesses and to present themselves as 'miracles' capable of inspiring the conversion of their fellow citizens.

Along with reaching out to vulnerable populations, the importance of being 'witness to the work of Jesus Christ' is also reflected in the economic activities engaged in by Reformation members. The organisation is partially funded through donations from members of Evangelical Christian Churches in Côte d'Ivoire and elsewhere, the reallocation of financial resources among Reformation's 70 national NGOs, as well as the profit-generating activities described in the previous section. However, 
Reformation also actively solicits donations of money, food products, clothing and construction materials from individuals and private companies. This involves spreading the word about Reformation's activities in public places, approaching well-to-do shoppers in front of malls, going door to door in residential neighbourhoods, and meetings with business owners. Residents justify their requests for support by testifying to the miraculous intervention of God in the lives of vulnerable individuals and by explaining the role played by Reformation's humanitarian aid.

Reformation's ability to continually expand its holistic rehabilitation programmes in Côte d'Ivoire ultimately depends on the ability of its members to broadly circulate narratives that celebrate the miraculous effect that God and the NGO have had on their lives. Whether they are told during Christian self-improvement activities for residents, at meetings with vulnerable individuals outside the centres, or while soliciting donations from potential donors, these stories of rehabilitation provide a broad and varied audience with an opportunity to witness the positive influence of God and Reformation on vulnerable groups. For example, a drop-out who had spent time as a street kid, an addict and a prisoner could explain how the NGO's holistic rehabilitation programme made it possible for him to reflexively transform himself into someone who - along with becoming literate, learning a trade, mastering a musical instrument and taking responsibility for a rehabilitation centre - had given his life to Jesus for the salvation of his neighbour. Such a story would provide an audience with all the elements necessary to recognise and acknowledge a miraculous divine intervention (Pelkmans 2015). Furthermore, a specific form of lifestyle evangelism lies at the heart of this process of sharing stories. It is deployed through the performance of a Christian citizenship that seeks to shape the behaviour of marginalised groups. This process of evangelisation begins by encouraging candidates for conversion to transform themselves. Thus, they meet with individuals who have already experienced a miraculous transformation and can demonstrate, through their own stories, that miraculous divine intervention is a possibility. Most importantly, the candidates recognise that this is a possibility not only for others, but in their own lives as well.

\section{Conclusion}

Reformation's plan consists of encouraging ethical self-transformation among marginalised groups in Western and postcolonial societies. It 
places the possibility of social change within the reach of any marginalised individual willing to engage in Christian self-forming activities that pave the way for their own salvation as well as the salvation of their fellow marginalised citizens. Working at the crossroads of local and transnational support networks, Reformation has expanded its programmes to a growing number of countries and communities thanks to the efforts of its members, who solicit material and financial resources from donors while pursuing the holistic healing of their fellow citizens. Just like numerous Pentecostal and charismatic Churches, Reformation's economic development model follows the principles of entrepreneurship and market-based development that are central to neoliberal ideology. However, the rehabilitation programmes offered by this Evangelical NGO do not reflect the prosperity gospel preached by these Churches. Rather, Reformation's programming reflects an ascetic approach based on an ethics of quarantine, as well as on individual and collective devotion to the salvation of marginalised fellow citizens.

Reformation's model of social change relies on a relatively standardised method, even if members' personal journeys and behaviours affect the details of their individual reflexive self-transformations. Thus, the organisation's rehabilitation programmes are based on the circular logic of mobilising of individuals who, after transforming themselves through Christian practices, assume the role of witnesses to God's power to miraculously change lives, and seek to inspire the conversion of their fellow citizens. Reformation's call to the marginalised has resonated and the self-forming activities through which residents cultivate a virtuous self have been successfully implemented in a variety of different linguistic and cultural contexts where the organisation operates, making it a prime example of a fbNGO that fosters religious mobility and the globalisation of Christianity (Csordas 2009).

Finally, Reformation conceptualises social change in such a way that the problem of marginalisation is located within the individual being rehabilitated, rather than being tied to issues of social inequality or sociopolitical dynamics. Although operating on the same level and in the same transnational space as state governmentalities, Reformation engages in forms of socioeconomic and spiritual activism that do not compete with, complement or support state activities (Ferguson 2006b). Rather, the organisation acts out of a desire to instigate and ensure the spread of Christian 'internal social movements' that change the world one individual at a time (O’Neill 2010a: 183; Zigon, 2011). In this way, the social change 
that Reformation seeks to achieve through the humanitarian aid it provides is primarily a matter of restoring the public virtue of each individual. But the organisation can also be studied as a 'transnational apparatus of governmentality' that aims to 'conduct the conduct' of vulnerable populations through standardised Christian self-forming activities. This alternative ethnographic viewpoint makes it possible to approach this Evangelical organisation - as well as other fbNGOs and transnational religious structures, such as mega-churches (O'Neill, 2010a) - not only as a source of socioeconomic and ethical alternatives for a growing number of highly vulnerable individuals, but as an alternative way of performing citizenship. 